\title{
Personalia
}

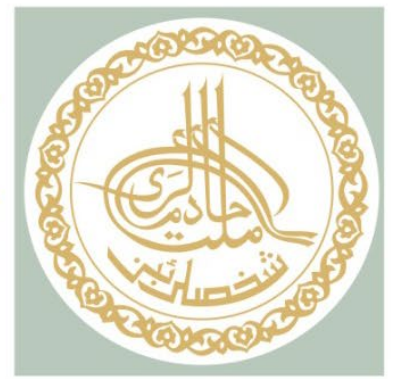

\section{RIZA FAKHRETDDINOV: AN OUTSTANDING RELIGIOUS FIGURE, SCIENTIST-ORIENTALIST, AND EDUCATOR}

Bulat L. Khamidullin, Institute of Tatar Encyclopedia and Regional Studies, Academy of Sciences of the Republic of Tatarstan, 56 Puskin Str., Kazan, 420111, Russian Federation, bulat.antat@mail.ru.

Riza (Rizaeddin) Fakhretddin (Fakhretddinov) (1859-1936) was a religious figure, scientist- orientalist, and educator. From 1889 to 1891, he was an Imam-Khatib of the mosque in the village of Ilbyakovo in the Bugulma County. In 1891, he was elected Qazi, meaning he became a member of the Orenburg Muslim Spiritual Assembly in Ufa. During

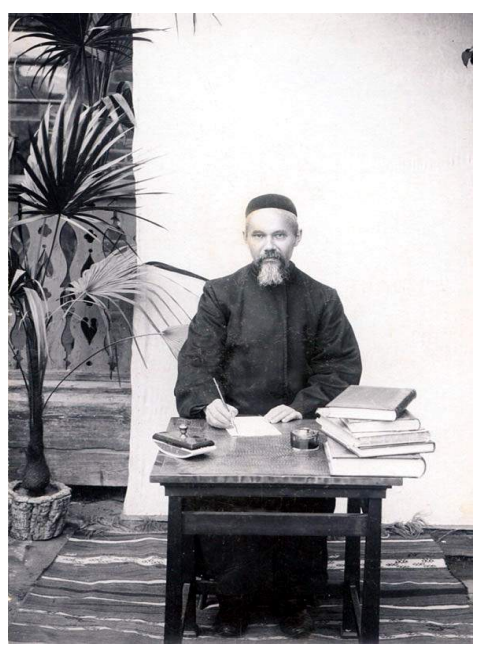

Риза (Ризаэтдин) Фәхретдин улы (Фәхретдинов) (1859-1936) - дин әһеле һәм жәмәгать эшлеклесе, шәрык белгече, мәгърифәтче. 1889-1891 елларда - Бөгелмә өязе Илбәк авылы мәчетенең имам-хатибы, 1891 елдан - Оренбург мөселман Диния нәзарәтендә (Уфа) казый. Шул ук елларда X-XX гасырның
Риза (Ризаэтдин) Фахретдин (Фахретдинов) (1859-1936) - религиозный и общественный деятель, востоковед, просветитель. В 1889-1891 гг. имам-хатиб мечети в д. Ильбяково Бугульминского уезда, с 1891 г. кази Оренбургского магометанского духовного собрания (Уфа). В эти же годы пишет свой широко известный био- 
the same years, Riza wrote his wellknown bibliographic work "Acap" ("Asar"), which presented a wealth of material about the outstanding personalities of the $10^{\text {th }}-20^{\text {th }}$ centuries. In 1906, he moved to Orenburg, found a job with the newspaper "Вакыт" ("The Time") and the magazine "Шypa" ("Council") and simultaneously supervised the madrasah "Хөсәения". Riza Fakhreddin promoted scientific knowledge and the reform of Islamic education. He paid much attention to the history of the Tatar people, their culture and philosophy and the problems of Muslims in Russia. By 1917 he had written over 60 books and 700 articles. In 1922, Riza became the Mufti of the Central Spiritual Board of Muslims in Russia and Siberia. He led the Soviet Muslim Delegation at the world Congress in Mecca in 1926. He claimed that religion without education was flawed, as was education without religion. He believed that Islam of the Prophet Muhammad's time did not contradict modern reality, on the contrary, it interpreted dogmas in accordance with the knowledge of the new time. The Memorial Museum was opened in honor of Riza Fakhretddin in the village of Kichuchatovo in the Republic of Tatarstan. The madrasah in Ufa, the central mosque and the madrasah in Almetyevsk are named after him. күренекле шәхесләре хакында бай материал тупланган һәм киң танылу алган күренекле «Асар» биобиблиографик хезмәтен яза. 1906 елда Оренбургка күчеп, «Вакыт» газетасында һәм «Шура» журналында эшли, бер үк вакытта «Хөсәения» мәдрәсәсенә житәкчелек итә. Фәнни белемнәрне пропагандалау белән шөгыльләнә, ислам мәгарифенә реформа ясау фикерен яклый, татар халкы тарихы, мәдәнияте һәм фәлсәфәсенә, Россия мөселманнары мәсьәләләренә зур игътибар бирә. 1917 елга кадәр 60 тан артык китап һәм 700 дән күбрәк мәкалә яза. 1922 елдан Үзәк Россия һәм Себер мөселманнарының Үзәк Диния нәзарәте мөфтие вазифасын башкара. 1926 елда Мәккәгә мөселманнарның Бөтендөнья конгрессына барган СССР делегациясен житәкли. Диннең мәгарифтән башка, ә мәгарифнең диннән башка тулы булмавын дәлилли, Мөхәммәд пәйгамбәр вакытындагы исламның хәзерге чынбарлыкка каршы килмәвен, алай гына да түгел, киресенчә, ислам кануннарын яңа заман белемнәренә туры китереп аңлатырга кирәклекне раслый. Уфадагы мәдрәсә, Әлмәттәге Үзәк мәчет һәм мәдрәсә аның исемен йөртә, Татарстан Республикасы Кичүчат авылында мемориаль музее ачылган. библиографический труд «Асар», в котором представлен богатый материал о выдающихся личностях Х-ХХ вв. В 1906 г. переехал в Оренбург, работал в газете «Вакыт» («Время») и журнале «Шура» («Совет»), одновременно руководил медресе «Хусаиния». Вел пропаганду научных знаний, выступал за реформирование исламского образования, много внимания уделял вопросам истории татарского народа, его культуре и философии, проблемам мусульман России. До 1917 г. написал более 60 книг и более 700 статей. С 1922 г. муфтий Центрального духовного управления мусульман Внутренней России и Сибири. В 1926 г. возглавлял делегацию СССР на Всемирном конгрессе мусульман в Мекке. Утверждал, что религия без образования ущербна, как и образование без религии, что ислам времени пророка Мухаммада не только не противоречит современной действительности, а наоборот, предполагает необходимость толкования его догматов в соответствии со знаниями нового времени. Его именем названо медресе в Уфе, центральная мечеть и медресе в Альметьевске, в с. Кичучатово РТ открыт мемориальный музей.
Rizaeddin Fakhretddinov was born in the village of Kichuchat in the Bugulma County Samara province (currently the village of Kichuchatovo in the Almetyevsk region in Tatarstan) into the family of imam Fakhretddin. According to all encyclopedias, this fact was recorded in the parish metric on the fourth of January, 1859. [Ainutdinova, p. 96], [Aminov]. He received the initial training from his mother Makhubabystai and from the autumn of 1865 to the end of 1880 , he continued his education in the madrasah of the village of Nizhnie Chershily and in the town of Chistopol. In the village madrasah, Riza combined his studies and teaching activities, as he stood out among his peers for his knowledge and literacy. In 1887, Riza Fakhretddin passed obligatory exams and received a certificate from the Orenburg Muslim Spiritual Assembly, giving him the right to hold the posi- tions of Imam-khatib and Mudarris. In 1887-1888, his first works "Ат-тухфат ал-анисия" ("A Gift to Friends") and "Китаб ал-игтибар" ("A Book of Trust") on teaching the Arabic language and Islamic law were published in Kazan. From 1889 to 1891, Riza was an Imam-khatib of the mosque in the village of Ilbyakovo in the Bugulma County. In 1891, he was elected Qazi of the Orenburg Muslim Spiritual Assembly.

In Ufa, Rizaeddin Fakhretddinov ("Riza kazy") put the archive of the Spiritual Collection in order and initiated the archeographic processing of its funds, as well as the publications of its most valuable documents. In the same years (before moving to Orenburg in 1906), he wrote the famous bibliographic work "Acap" ("Monuments" / "Traces"), which contained a great amount of material about more than one thousand famous Muslim scientists 
and statesmen of the $10^{\text {th }}-20^{\text {th }}$ centuries. The data in "Acap" presented the historical development of the Tatar people's scientific knowledge, following national traditions of studying history, established earlier by Hussain Amirkhan and Shigabutdin Marjani. It included an essay, based on "Ножуметтаварих" ("The Star of Stories") and "Вафийат ал-аслафватахийат ал-ахлаф" (“Obituaries and Covenants for Posterity”) [Khamidullin, pp. 206211]. It is difficult to overestimate the value of "Acap" as a historical work, containing the data from a huge number of written and oral sources [Amirkhan], [Baibulatova, 2006].

It is necessary to note that one of the main topics of Riza's historical research was the Volga Tatars' ethnogenesis and the origin of the ethnonym "Tatars". His views can be summarized in several main points. While continuing the historiographical tradition of Husain Amirkhan in many ways, Riza treated the ethnonym "Tatars" negatively and with a clear dismissive attitude. Unlike his spiritual guide Shigabutdin Marjani, he never used it in relation to his people. "Our national name", - wrote Rizaeddin Fakhreddinov, - "is the Northern Turks". He used the name "Tatars" only as a synonym for the ethnonym "Mongols". According to the researcher, the term "Tatar" means "a rider", and it referred to a special military unit of Genghis Khan vanguard troops. Under the first Chingissids, this name was used to name all Eurasian TurkicMongolian ethnic groups. This name was adopted by the Golden Horde's rulers (when the word "Tatars" meant representatives of the highest social stratum), and later, it was adapted to all vassal people, in particular to the "Bulgarian Turks".

Riza Fakhretddin actively used the terms "Bulgar Turks", "Northern Turks", "Kazan Turks", and "Muslim Turks" in the designation of Kazan Tatars to show the difference between modern Tatars and the population ruled by Genghis Khan, as well as the Turks of Asia Minor. Over the 2nd and 3rd periods of the people's history as "the Bulgar Turks under the rule of the Tatars and Russians" [Fakhretddinov, pp. 49-53], he excluded any ethnic connection between Muslim "Bulgar Turks" and pagan "Tatars" during the campaigns of Genghis Khan's grandson Batu. Condemning the Mongol campaigns of the first Chingissids, Riza wrote: "Stunned by the blow of the Tatar invasion, the Islamic world has not been able to rise to its feet for seven centuries". At the same time, Riza Fakhretddin did not hide his sympathy with the Golden Horde (he called it, in particular, "the Great Turkic State"), which separated from the Mongolian
Empire under the successors of Batu. This Golden Horde was a Turkic state in terms of population and culture, ruled by the Mongol-Tatar dynasty. The scholar, like Marjani, developed the idea of the historical continuity of Volga Bulgaria, the Golden Horde, the Kazan Khanate and modern "Bulgarian Turks" - "the Turkic-Muslims" from the Volga region, living in the Kazan, Samara, Ufa, Orenburg, Vyatka, Saratov, and Astrakhan provinces.

Paying attention to the continuity between Volga Bulgaria and the Kazan Khanate, Riza notes the fact that Bulgarian Emir Alimbek was overthrown by Khan Ulug-Mohammed who came from the Golden Horde. He was the one who became the ruler of the "Bulgar and Kazan Turks" and founded the Khan's dynasty in the "Kazan and Bulgar state". However, according to Riza Fakhretddin, the change of dynasties did not mean that the state's population became Mongolian (Tatar), as Ulug-Muhammad brought with him only three thousand people. One third of these people were soldiers. "The local people, entirely composed of Turks, were called 'Tatars' owing to the Khan and his entourage". "In fact, Tatars were merely a drop in the bucket", writes Riza. He considered that the "Bulgar Turks" united with Ulug Muhammad, the Chuvash and Mari people demonstrated their obedience and asked for protection from the raids of the Russians. Thus, Riza Fakhretddin noted that Kazan "was revived" in 1439 and began its new history [Ibid, pp. 206-211].

The books "Жәвамигуль-кәлимшәрхе" ("Comments on the Collections of Sayings", Orenburg, 1911) and "Динивә ижтимагый мәсьәләләр" ("Religious and Social Problems", Orenburg, 1914) hold a special place among his scientific research, describing in detail the author's religious views. Riza Fakhretddin claimed that religion without education was flawed, as was education without religion, and he proved that Islam of the Prophet Muhammad's time did not contradict the modern reality, on the contrary, it interpreted its dogmas in accordance with the knowledge of the new time. He criticized pagan practices and was against the worship of various saints, spirits, etc. [Ainutdinov], [Baibulatova, 2013], [Gainetdin], [Islamov].

Riza Fakhretddin was awarded silver and gold medals "For Diligence" on the Stanislavsky Ribbon for his service in the Spiritual Assembly. In 1906, he moved to Orenburg at the invitation of the brothers Shakir and Zakir Ramiev and found a job with the newspaper "Вакыт" ("The Time"). He was the editor-in-chief of the magazine "Шура" 
("The Council") and simultaneously supervised the madrasah "Хөсәения" [Gosmanov, 2008], [Hamidullin]. He promoted the scientific knowledge and the reform of Islamic education. He paid much attention to the history of the Tatar people, their culture and philosophy and the problems of Muslims in modern Russia. He published such works as "Русия мөселманларның ихтыяжлары вәаларның хакында интикад” (“Muslims' Needs in Russia, and Their Criticism", 1906), "Исламлар хакында хөкүмәттәд бирләре" (“State Administration of Muslims", 1907), etc. As a result, Riza Fakhretddin had published about 100 books (including reprints) by 1917, and more than 700 of his articles had been published in Tatar newspapers and magazines [Gainetdin]. Unfortunately, not all of Riza Fakhretddin's works are available to readers. Some of them remain unpublished, in particular, the two-volume "Юаныч" ("Consolation"), in which the author shared his thoughts about the world, religion, history, and literature, culture and morality, etc. [Baibulatova, 2006].

Riza moved to Ufa in 1918 and became the Mufti of the Central Spiritual Board of Muslims from Inner Russia and Siberia in 1922. As a guest of honor, he took part in the celebrations dedicated to the 200th anniversary of the Academy of Sciences of the USSR in 1925. This testified to his high authority in the scientific community. He led the Soviet Muslim Delegation at the World Congress in Mecca in 1926 and was elected VicePresident of the Congress [Gosmanov, 1984], [Rizaeddin Fakhretddin], [Huseinov].

In the second half of the 1920s, the Soviet confessional policy changed dramatically. Riza's quite loyal attitude was affected by serious pressure on religion in the country, which resulted in the repression of the clergy, in the closure of parishes, and in the prohibition of religious education. In 1930, Riza Fakhretddin was going to resign from the Spiritual Central Board of Muslims together with the other members to draw attention of the world community to the situation of Islam in the USSR. The great Tatar scholar, theologian, and educator died on the $12^{\text {th }}$ of April, only a few months before mass arrests of the Central Spiritual Board of Muslims' leadership [Ainutdinov], [Gosmanov, 1984].

\section{References}

Ainutdinova, L. M. (2014). Fakhretddin Rizaeddin [Fakhretddin Rizaeddin]. Tatars kaia entsiklopediia: v 6 t. T. 6, pp. 96-97. Kazan. (In Russian)
Aminov, T. M. (2019). Fakhretddinov Rizaeddin [Fakhretddin Rizaeddin]. Bashkirskaia-entsiklopediia.rf: Bashkirskaia entsiklopediia. URL: http://www.xn---7sbacsfsccnbdnzsqis3h5a6ivbm.xn--

p1ai/index.php/component/content/article/2-statya/422fakhretdinov-rizaitdin-fakhretdinovich (accessed: 04.01.19). (In Russian)

Baibulatova, L. F. (2006). “Asar" Riza Fakhretddin: istochnikovaia osnova $i$ znachenie svoda. ["Asar" Fakhretddin Rizaeddin: Source Basis and the Value of the Set]. 174 p. Kazan. (In Russian)

Baibulatova, L. F. (2013). Rizaetddin Fakhretddin o rossiiskom musulmanskom soobshchestve $i$ ego problemakh posle 1905 (po materialam gazety "Vakyt" I zhurnala "Islam") [Rizaetddin Fahretddin about the Russian Muslim Community and Its Problems after 1905 (based on the newspaper "The Time" and the magazine "Islam")]. Türkolojiüzerinearaştırmalar. 5. Afyonkarahisar, pp. 133-142. (In Russian)

Omirkhan, R. (1992). Riza Fokhreddinev tarikhchy [Riza Fakhretddinov as a Historian]. Miras, No.12, pp. 64-73. (In Tatar)

Fəkhreddinev, R. (1993). Bolgarva Kazan toreklare [From Bulgarians to Kazan Turks]. 287 p. Kazan. (In Tatar)

Gainetdin, M. (2003). Riza Fəkhreddinov publitsist [Riza Fakhretddinov as a Publicist]. Rizaeddin Fakhreddin: Mirasyhəmkhəzerge zaman: Məkalələrжyentygy. Kazan, pp. 163-170. (In Tatar)

Gosmanov, M. (1984). Katlaulychornyн karshylykly vakile [A Controversial Representative of the Difficult Era]. Kazan utlary, No. 1, pp. 142-157. (In Tatar)

Gosmanov, M. (2008). Tarikhybyzny tutykmas ber kozgese: ("Shura" zhurnalyna 100 el) [The Fearless Mirror of Our History: The Magazine 'Shura']. Kazan utlary. No.1, pp. 152-155. (In Tatar)

Islamov, F. F. (2003). Rizaeddin Fakhreddinov mashhyrmag rifatche, pedagog [Rizaeddin Fahretddinov as a Famous Educator and Teacher]. Rizaeddin Fakhreddin: Mirasyhəmkhəzerge zaman: Məkalələrжyentygy. Pp. 188-205. Kazan. (In Tatar)

Khamidullin, B. L. (2018). “...Okaiannaia dver' Zlatoi ordy...": ocherki i istoriograficheskie zametki po istorii Zolotoi Ordyi Kazanskogo khanstva. [“...The Cursed Door of the Golden Horde...": Essays and Historiographical Notes on the Golden Horde's and the Kazan Khanate's History]. 295 p. Kazan'. (In Russian)

Khəmidullin, L. (2002). Ramievlar matbagasy [Ramiev's Printing Office]. Bertugan Rəmievlər. Fənnibiografikжyentyk. Pp. 69-79. Kazan. (In Tatar)

Khesəienov, F. B. (1997). Rizaitdin bin Fəkhretdin. Tarikhi-biografikkitap. [Rizaeddin Fakhreddin. The Historical Biography]. 304 p. Өfe. (In Bashkir)

Rizaeddin Fakhreddin. (2014). Zhizn' dlinoiu $v$ vechnost' [Eternity of Life]. Avt.-sost. Gimranova D. G., Gubaidullina L. I., Minnullin R. Kh. 148 p. Kazan. (In Russian) 


\title{
РИЗА ФАХРЕТДИНОВ: ВЫДАЮЩИЙСЯ РЕЛИГИОЗНЫЙ ДЕЯТЕЛЬ, УЧЕНЫЙ-ВОСТОКОВЕД И ПРОСВЕТИТЕЛЬ
}

\author{
Булат Лиронович Хамидуллин, \\ Институт татарской энциклопедии и регионоведения \\ Академии наук Республики Татарстан, \\ Россия, 420111, Казань, ул. Пушкина, д. 56, \\ bulat.antat@mail.ru.
}

Ризаэтдин Фахретдинов родился в деревне Кичучат Бугульминского уезда Самарской губернии (ныне село Кичучатово Альметьевского района РТ) в семье имама Фахретдина. 4 января 1859 г. этот факт был письменно зафиксирован в приходской метрике, о чем нам сообщают все энциклопедии [Айнутдинова, с. 96], [Аминов]. Первые знания получил в семье от обучавшей его матери Махубы абыстай, а затем (с осени 1865 по конец 1880-х гг.) продолжил образование в медресе деревни Ниж. Чершилы и города Чистополя. В деревенском медресе он совмещал учебу с преподавательской деятельностью, так как выделялся среди своих сверстников знаниями и грамотностью. В 1887 г. Риза Фахретдин сдал необходимые экзамены и получил свидетельство Оренбургского магометанского духовного собрания, дающее ему право занимать должности имам-хатиба и мударриса. В 1887-1888 гг. в Казани были опубликованы его первые сочинения «Ат-тухфат ал-анисия» («Подарок друзьям») и «Китаб ал-игтибар» («Книга доверия»), посвященные вопросам преподавания арабского языка и исламского права. В 1889-1891 гг. был имам-хатибом мечети в деревне Ильбяково Бугульминского уезда. В 1891 г. избран кази (судьей) Оренбургского магометанского духовного собрания.

Будучи в Уфе, Ризаэтдин Фахретдин («Риза казый») привел в порядок архив Духовного собрания и положил начало археографической обработке его фондов, а также публикаций наиболее ценных документов. В эти же годы (до переезда в 1906 г. в Оренбург) он написал свой знаменитый биобиблиографический труд «Асар» («Памятники» / «Следы»), в котором представлен большой по объему и богатый по содержанию материал о более чем одной тысячи известных мусульманских ученых и государственных деятелей $\mathrm{X}$ - начала XX века. Сведения, представленные в «Асар» и отразившие формирование исторических научных знаний татарского народа, позволили продолжить традицию изучения национальной истории, заложенную ранее Хусаином Амирханом и
Шигабутдином Марджани: указанное сочинение написано на примере «Ножумет-таварих» («Звезда историй») первого и «Вафийат аласлаф ва тахийат ал-ахлаф» («Некрологи предшественникам, заветы потомкам») второго [Хамидуллин, с. 206-211]. Значение «Асар» как исторического труда, базирующегося на сведениях огромного количества письменных и устных источников, трудно переоценить [Әмирхан], [Байбулатова, 2006].

Отдельно отметим, что одной из главных тем исторических изысканий Ризы Фахретдина являлся этногенез поволжских татар и происхождение самого этнонима «татары». Его взгляды можно свести к нескольким основным тезисам. Во многом продолжая историографическую традицию Хусаина Амирхана, он, в отличие от своего духовного наставника Шигабутдина Марджани, относился резко отрицательно - причем с явным пренебрежительным оттенком - к этнониму «татары» и никогда не употреблял его по отношению к своему народу. «Наше национальное имя, - писал Ризаэтдин Фахретдинов, - северные тюрки». Название «татары» использовалось им лишь как синоним этнонима «монголы». По мнению ученого, «татар» означает «всадник», так первоначально называли специальное воинское подразделение авангарда войск Чингисхана, затем при первых Чингисидах это имя было перенесено на все евразийские тюрко-монголоязычные этносы, его приняли правители Золотой Орды (при которых слово «татары» обозначало представителей высших слоев общества), и позднее оно перешло на все вассальные им народы, в частности на «булгарских тюрок». Риза Фахретдин при обозначении казанских татар активно употреблял термины «булгарские тюрки», «северные тюрки», «казанские тюрки», «тюркимусульмане», чтобы рельефнее показать отличие современных ему татар от подвластного Чингисхану населения, а также от турков Малой Азии. Объявив 2-й и 3-й периоды истории своего народа как «Булгарские тюрки под властью татар и русских» [Фәхреддинев, с. 49-53], 
он исключал всякую этническую связь между мусульманами «булгарскими тюрками» и язычниками «татарами» периода походов внука Чингисхана Бату. Осуждая монгольские походы первых Чингисидов, он писал: «Оглушенный дубиной татарского нашествия, исламский мир не может встать на ноги вот уже семь столетий». При этом Риза Фахретдин не скрывал своих симпатий к выделившейся из состава Монгольской империи при преемниках Бату Золотой Орде (ее он называл, в частности, «Великим Тюркским государством»), являвшейся тюркским по составу населения и культуре государством с правящей монголо-татарской династией. Ученый, как и Ш. Марджани, развивал идею исторической преемственности Волжской Булгарии, Золотой Орды, Казанского ханства и современных автору «булгарских тюрок» «тюрко-мусульман» Поволжья, проживающих в Казанской, Самарской, Уфимской, Оренбургской, Вятской, Саратовской и Астраханской губерниях. Говоря о преемственности Волжской Булгарии и Казанского ханства, он отдельно отмечал факт свержения с престола булгарского эмира Алимбека выходцем из Золотой Орды ханом Улуг-Мухаммедом, который сам стал правителем «булгарских и казанских тюрков» и основал ханскую династию в «Казанском и Булгарском государстве». Однако, по убеждению Ризы Фахретдина, смена династий не означала, что население государства стало монгольским (татарским), поскольку УлугМухаммед привел с собой всего лишь 3 тысячи человек, из которых воины составляли одну тысячу. «Здешний народ, хотя целиком состоял из тюрок, получил название ,татары“, но этим он обязан лишь хану и его приближенным. На деле же татар здесь содержалось не более как капля в море», - писал исследователь. «Булгарские тюрки», по свидетельству историка, объединились вокруг Улуг-Мухаммеда, а чуваши и марийцы выразили свою покорность и попросили защитить их от русских набегов. Таким образом, отмечал Риза Фахретдин, в 1439 г. Казань «возродилась» и началась ее новая история [Там же, с. 206-211].

Особое место среди его научных исследований занимают книги «Жәвамигуль-кәлим шәрхе» («Комментарии к собраниям изречений», Оренбург, 1911) и «Дини вә ижтимагый мәсьәләләр» («Религиозные и общественные проблемы», Оренбург, 1914), в которых были достаточно подробно изложены религиозные воззрения автора. Риза Фахретдин утверждал, что религия без образования ущербна, как и образование без религии, и доказывал, что ислам времен пророка Мухаммада не только не противоречит современной действительности, а наоборот, предполагает необходимость толкования его догматов в соответствии со знаниями нового времени. Критиковал языческие пережитки и выступал против поклонения различным святым, духам и т. д. [Айнутдинова], [Байбулатова, 2013], [Гайнетдин], [Исламов].

За свою службу в Духовном собрании Риза Фахретдин был награжден серебряной и золотой медалями «За усердие» на Станиславской ленте. В 1906 г. по приглашению братьев Шакира и Закира Рамиевых он переехал в Оренбург, где работал в газете «Вакыт» («Время»), был главным редактором журнала «Шура» («Совет») и одновременно руководил медресе «Хусаиния» [Госманов, 2008], [Хәмидуллин]. Здесь он вел активную пропаганду научных знаний, выступал за реформирование исламского образования, много внимания уделял проблемам истории татарского народа, его культуре и философии, проблемам мусульман в современной ему России. В эти годы были опубликованы такие его сочинения, как «Русия мөселманларның ихтыяжлары вә аларның хакында интикад» («Нужды мусульман России и их критика», 1906), «Исламлар хакында хөкүмәт тәдбирләре» («Государственное управление мусульманами», 1907) и др. В итоге до 1917 г. было издано около 100 книг Ризы Фахретдина (с учетом переизданий), а также опубликовано более 700 его статей на страницах татарских газет и журналов [Гайнетдин]. К сожалению, до сих пор не все творчество Ризы Фахретдина доступно читателям: остаются неизданными некоторые его произведения, в частности двухтомник «Юаныч» («Утешение»), в котором автор делится своими мыслями о мире, религии, истории и литературе, культуре и нравственности и т. д. [Байбулатова, 2006].

В 1918 г. Риза казый переехал опять в Уфу. С 1922 г. он муфтий Центрального духовного собрания мусульман Внутренней России и Сибири. В 1925 г. в качестве почетного гостя принимал участие в торжествах, посвященных 200летию Академии наук СССР, что, безусловно, свидетельствует о его высоком авторитете в научных кругах. В 1926 г. возглавлял делегацию СССР на Всемирном конгрессе мусульман в Мекке и даже был избран вице-президентом конгресса [Госманов, 1984], [Ризаэддин Фахреддин], [Хөсәйенов]. 
Во второй половине 1920-х гг. конфессиональная политика советской власти резко изменилась. Вполне лояльное отношение сменилось неприятием религии, что выразилось в репрессиях в отношении духовенства, закрытии приходов, запрещении религиозного образования. Дело дошло до того, что в 1930 г. Риза Фахретдин собирался подать в отставку вместе с другими членами ЦДУМ, дабы обратить внимание всего мирового сообщества на положение ислама в СССР. Не дожив всего несколько месяцев до массовых арестов руководства ЦДУМ, великий татарский ученый, богослов и просветитель умер 12 апреля 1936 г. [Айнутдинова], [Госманов, 1984].

\section{Литература}

Айнутдинова Л. М. Фахретдин Ризаэтдин // Татарская энциклопедия: в 6 т. Т. 6. Казань, 2014. С. 96-97.

Аминов Т. М. Фахретдинов Ризаитдин // Башкирская-энциклопедия.рф: Башкирская энциклопедия, 2019. URL: http://www.xn7sbacsfsccnbdnzsqis3h5a6ivbm.xn-

p1ai/index.php/component/content/article/2-statya/422fakhretdinov-rizaitdin-fakhretdinovich (дата обращения: 04.01.19).

Байбулатова Л. Ф. «Асар» Ризы Фахреддина: источниковая основа и значение свода. Казань, 2006. $174 \mathrm{c}$.
Байбулатова Л. Ф. Ризаэтдин Фахретдин о российском мусульманском сообществе и его проблемах после 1905 г. (по материалам газеты «Вакыт» и журнала «Ислам») // Türkoloji üzerine araştırmalar. 5. Afyonkarahisar, 2013. S. 133-142.

Ризаэддин Фахреддин: Жизнь длиною в вечность / авт.-сост. Д. Г. Гимранова, Л. И. Губайдуллина, Р. Х. Миннуллин. Казан, 2014. 148 с.

Хамидуллин Б. Л. «...Окаянная дщерь Златой орды...»: очерки и историографические заметки по истории Золотой Орды и Казанского ханства. Казань, 2018. 295 с.

Әмирхан Р. Риза Фәхреддинев - тарихчы // Миpac. 1992. № 12. 64-73 б.

Гайнетдин М. Риза Фәхреддинов - публицист // Ризаэддин Фәхреддин: Мирасы һәм хәзерге заман: Мәкаләләр жыентыгы. Казан, 2003. 163-170 б.

Госманов М. Катлаулы чорның каршылыклы вәкиле // Казан утлары. 1984. № 1. 142-157 б.

Госманов М. Тарихыбызның тутыкмас бер көзгесе: («Шура» журналына 100 ел) // Казан утлары. 2008. № 1. 152-155 б.

Исламов Ф. Ф. Ризаэддин Фәхреддинов мәшһүр мәгърифәтче, педагог // Ризаэддин Фәхреддин: Мирасы hәм хәзерге заман: Мәкаләләр жыентыгы. Казан, 2003. 188-205 б.

Фәхреддинев Р. Болгар вә Казан төрекләре. Казан, 1993. 287 б.

Хәмидуллин Л. Рәмиевләр матбагасы // Бертуган Рәмиевләр: Фәнни-биографик жыентык. Казан, 2002. 69-79 б.

Хөсәйенов $Ғ$. Б. Ризаитдин бин Фәхретдин. Тарихи-биографик китап. Өфө, 1997. 304 б. 